Research Journal of Applied Sciences 7 (1): 1-9, 2012

ISSN: $1815-932 \mathrm{X}$

(C) Medwell Journals, 2012

\title{
Preliminary Structural Study of Landsat Imagery over Wamba and Environs, Nasarawa State, Northcentral Nigeria
}

\author{
${ }^{1}$ G.K. Anudu, ${ }^{1}$ S.E. Obrike, ${ }^{1}$ S. Iyakwari and ${ }^{2}$ A.E. Ikpokonte \\ ${ }^{1}$ Department of Geology and Mining, Nasarawa State University, Keffi, Nigeria \\ ${ }^{2}$ Department of Geology, Ahmadu Bello University, Zaria, Kaduna State, Nigeria
}

\begin{abstract}
Wamba and environs is underlain by the migmatities, gneisses, Older Granites, Younger Granites, Awgu Shale and Lafia Formation. LANDSAT 5-TM imagery over the area has been analysed and interpreted in order to determine the lineament trends, drainage network and lineament density across the area. Rose (azimuth-frequency) diagram plots of the structures (lineaments) from both the imagery and field measurements show NE-SW, NNE-SSW, E-W, NNW-SSE and N-S directions with the dominant trends in the NE-SW and NNESSW directions. Two prominent faults (F1, F2) were identified on the imagery. The superposition of the lineament map and drainage map depicts that the dendritic drainage pattern of the area is lithologically and structurally controlled. The lineament map, lineament density contour map, lineament density image map and lineament density surface map show that the lineament density is high around Monkwar, Zamatak, Ninkade, Mugu, Gwanzu and Garko underlain by migmatites, gneisses and Older Granites.
\end{abstract}

Key words: Wamba, LANDSAT 5-TM, lineament, trends, drainage, granites, density

\section{INTRODUCTION}

The study of lineaments from LANDSAT imagery has been applied successfully to structural geology studies in different parts of the world (Karnieli et al., 1996; Mostafa and Zakir, 1996; Arlegui and Soriano, 1998; Suzen and Toprak, 1998; Zakir et al., 1999). There are lots of structural lineaments in the Nigerian Basement Complex as results of different tectonic deformations or episodes in which these rocks had undergone at various time. This has resulted into variable structural lineaments in which the initial structures have been superimposed by later structures.

Mapping of these structures on the field is sometime very tedious as result of poor exposures and accessibility as well as paucity of the rocks. Therefore, a more convenient way to map these structures is usually through analysis and interpretation of LANDSAT imagery. According to Odeyemi et al. (1999) the major structural feature of the Nigerian Basement Complex is the widespread occurrence of lineaments as defined by joints, shear zones, mylonites, faults, strike ridges and straight channelled streams. Also, the lineaments in the Basement Complex rocks are attributable to the presence of joints, faults, shear deformation, foliation, dykes and veins and are products of Pan-African deformational episode (Bassey et al., 2006). The principal structural directions are N-S, NNE-SSW, NE-SW, NNW-SSE and NW-SE
(Oluyide, 1988). It stated that the NE-SW and NW-SE conjugate sets of fractures represent strike-slip faults with the NE-SW fractures representing dextral sense of movement of faults. The variations in the orientations of the lineaments is due to the polycyclic history and brittle nature of the migmatites, gneisses and quartzites that constitute $>70 \%$ of the Nigerian Basement Complex rocks.

Based on analysis and interpretation of LANDSAT 5-TM imagery over Wamba and environs, this study presents the lineament patterns, drainage structures and lineament density across the area. The study area is located in Nasarawa State, Northcentral Nigeria (Fig. 1). It covers Wamba, Nasarawa Eggon, Garko, Shabu, Adogi, Assakio, Tunga, Utani, Panda, Nakere, Ninkade, Angwa Madaki, Lange, Arikya, Kumuru, Zamatak and Monkwar. It is located between latitudes $8^{\circ} 30^{\prime}$ and $9^{\circ} 00 \mathrm{~N}$ and longitudes $8^{\circ} 30^{\prime}$ and $9^{\circ} 00^{\prime} \mathrm{E}$ (Fig. 2). It is accessible through three major roads, namely: the Abuja-KeffiAkwanga-Lafia road, Makurdi-Lafia road and Jos-NamuLafia road. The area falls within the Guinea Savannah belt of Nigeria characterised by scattered tall trees, grasses, shrubs and herbs (Olorode, 2002). The climate is characterised by two seasons, namely; the rainy season and dry season. The rainy season lasts from April to October whereas the dry season covers from November to March. The mean annual rainfall is between $1000-1500 \mathrm{~mm}$ while the mean temperature is about $25.6^{\circ} \mathrm{C}$

Corresponding Author: G.K. Anudu, Department of Geology and Mining, Nasarawa State University, Keffi, Nigeria 


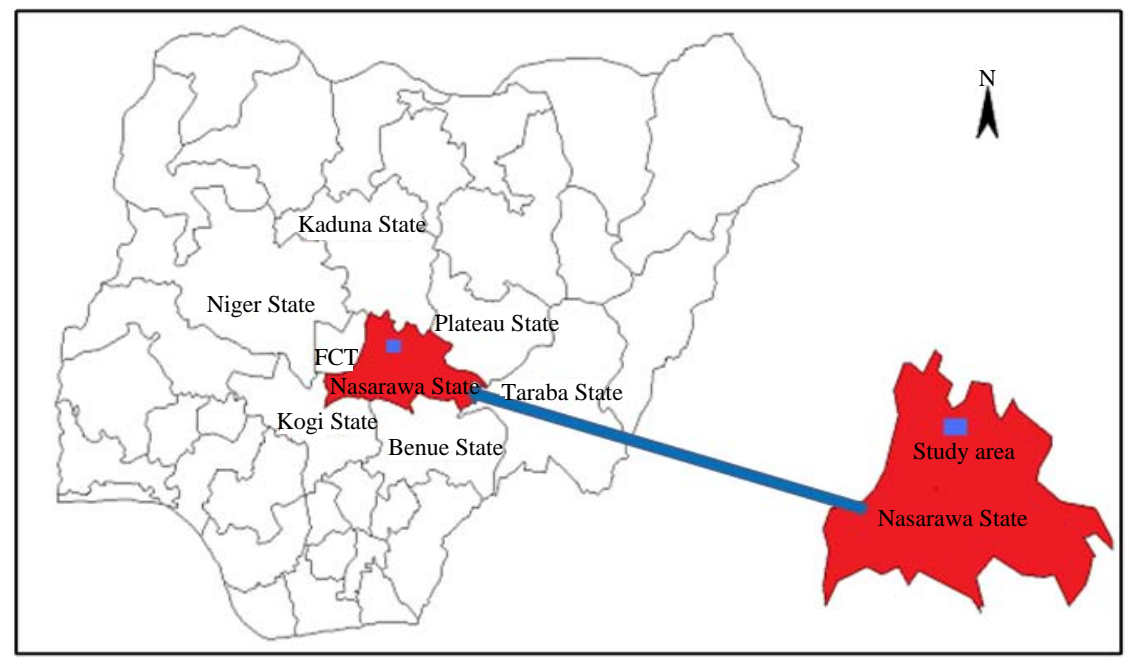

Fig. 1: Map of Nigeria showing the location of the study area in Nasarawa State

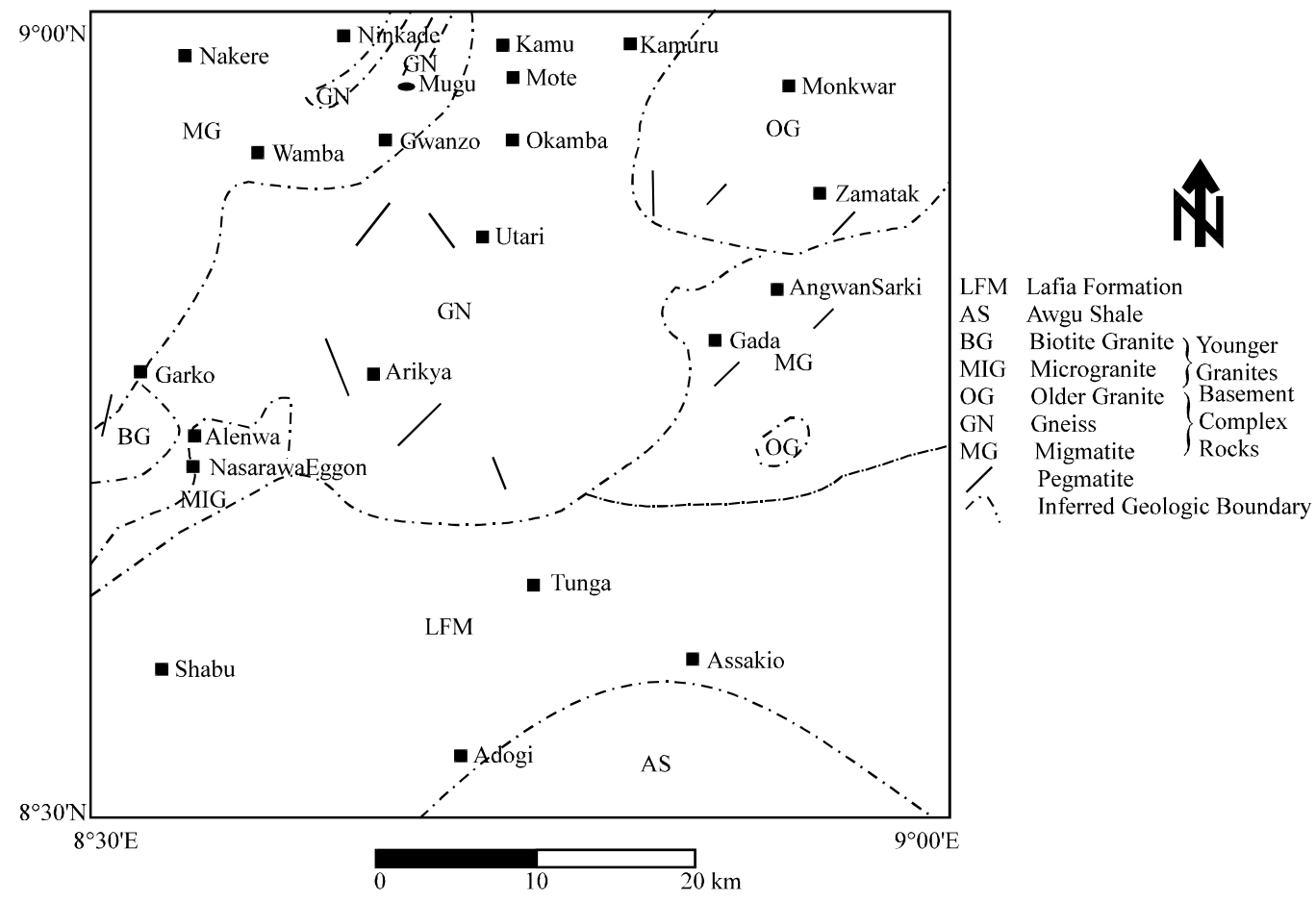

Fig. 2: Geological map of Wamba and environs (Macleod et al., 1971)

(Inyang, 1975; Akintola, 1986). The study area is underlain by the Basement Complex rocks, Younger Granites and the Cretaceous sedimentary rocks of the Middle Benue Trough (Fig. 3). The Basement Complex rocks in the area are divided into two, namely Migmatite-Gneiss Complex and the Older Granites (or Pan-African granitoids). The Migmatite-Gneiss Complex is Archaean (>2,500 million years) in age and consists mainly of migmatites and gneisses. It is the most extensive rock type and usually occupies low plains. The Older Granites (or Pan-African granitoids) are Pan-African (about $600 \pm 50$ million years) in age and consist mainly of granites, diorites and dolerites. They range from small plutons to large batholiths that form smooth-domed hills or inselbergs that are intrusive into the Migmatite-Gneiss Complex. The pegmatite dikes are usually widespread in the Migmatite-Gneiss Complex and Older Granites and usually trend in the following directions: N-S, NNE-SSW, 
Res. J. Applied Sci., 7 (1): 1-9, 2012

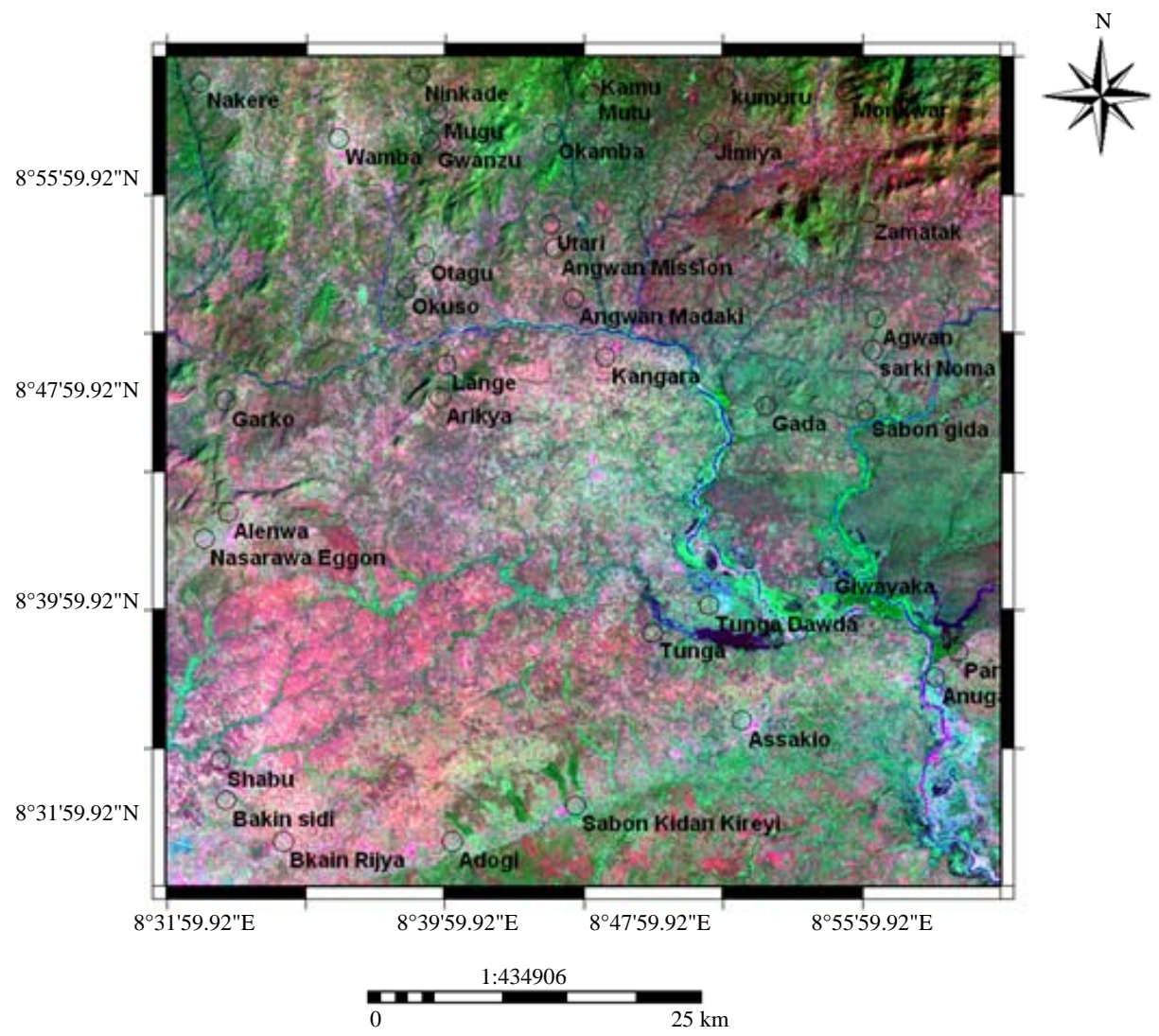

Fig. 3: LANDSAT 5-TM imagery over Wamba and environs

NE-SW and NNW-SSE (Fig. 3). The Younger Granites are Jurassic to Triassic (140-300 million years) in age and are intrusive into the Migmatite-Gneiss Complex. They are high-level, anorogenic granites. They consist mainly of microgranites and biotite granites in the study area. The southern part of the study area is underlain by the Cretaceous sedimentary rocks namely: the Awgu Shale and Lafia Formation. The Awgu Shale is composed mainly of gray shales whereas the Lafia Formation consists mainly of sandstone and covered a larger part of the southern area.

\section{MATERIALS AND METHODS}

The imagery of Wamba and environs (Fig. 2) is part of the whole satellite map of Nigeria acquired by Geomatics International Inc., for the Federal Department of Ministry of Agriculture and Natural Resources. It was selected from a main LANDSAT 5-TM (Thematic Mapper) scene P188r54 covering the area. As a result of the visual evaluation, the LANDSAT TM band 5 was included in the selected bands for this study because they offer a good contrast and improve the comparison between the lineaments researchers consider geological that are shown on this band and those from other bands. Hence, the RGB
521 was selected and used for the interpretation. The lineaments identification was achieved using the classical imagery interpretation techniques (Gardner and Miller, 1977; Burdick and Speirer, 1980; Drury, 1987; Karnieli et al., 1996; Baumgartner et al., 1999; Hung et al., 2002, 2005; Hung and Batelaan, 2003; Kim et al., 2004) and the following computer software and algorithms, namely ILWIS 3.3 and Golden SURFER 8.2 were employed. The LANDSAT 5-TM imagery of Wamba and environs is shown in Fig. 2. Both the structural lineaments and drainage patterns were mapped using ILWIS 3.3. The statistical analyses of orientations of these structures were done using Grapher 5 Software. The Golden SURFER 8.2 was used to construct the lineament density maps of the area.

\section{RESULTS AND DISCUSSION}

Structural analysis: The lineaments identified and delineated on the LANDSAT 5-TM imagery over Wamba and environs are more concentrated on the Basement rocks (migmatites, gneisses and Older Granites) than Younger Granites and Cretaceous sedimentary rocks (Awgu Shale and Lafia Formation) (Fig. 4). This is due to the effects of the widespread Pan-African orogeny 


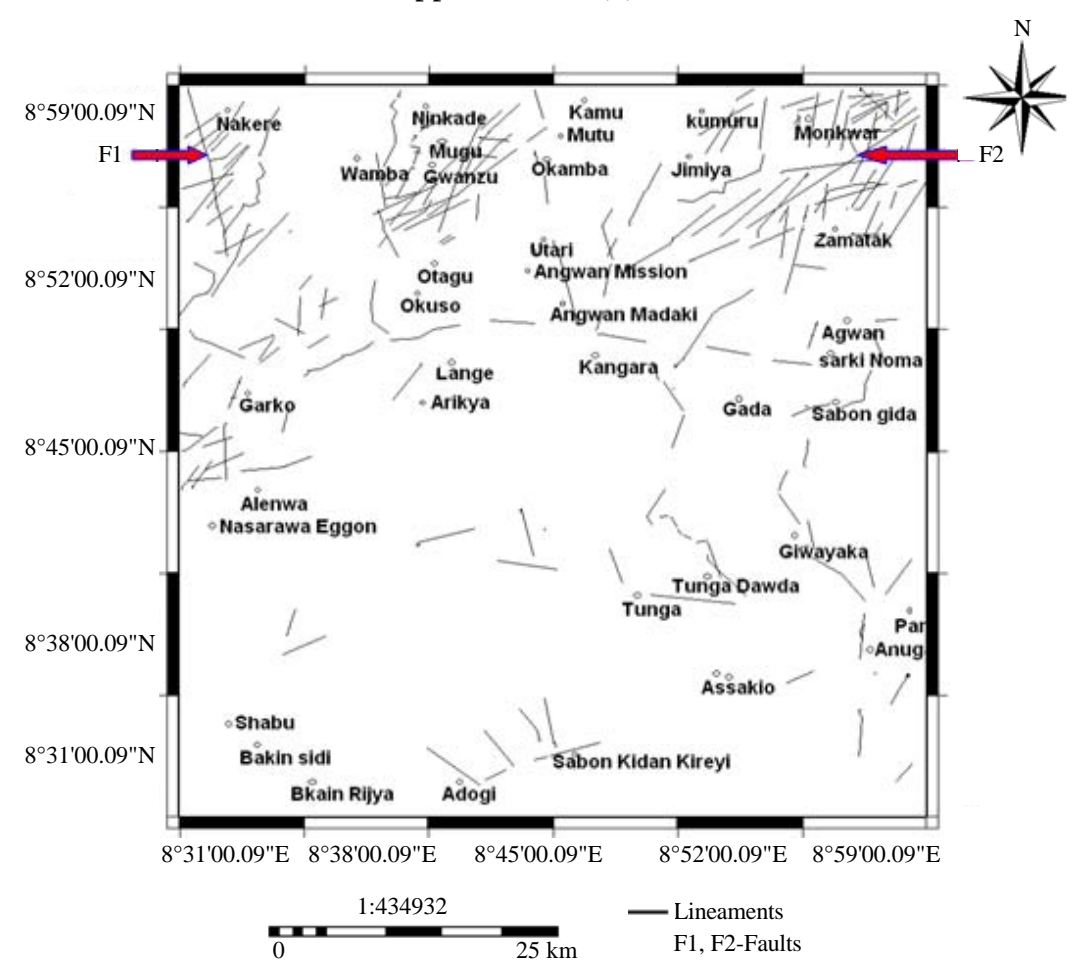

Fig. 4: Lineament map derived from LANDSAT 5-TM imagery over Wamba and environsc

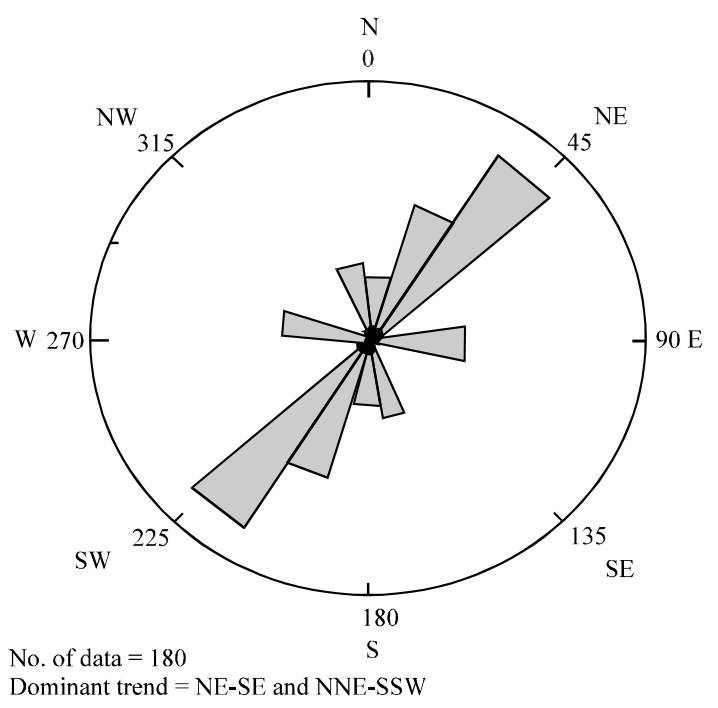

Fig. 5: Rose diagram of lineaments orientation obtained from LANDSAT 5-TM of the area

$(600 \pm 150 \mathrm{Ma})$ that was experienced in the Nigerian Basement rocks. The rose (azimuth-frequency) diagram for the delineated lineaments from the imagery is shown in Fig. 5. The major trends of the lineaments are NE-SW and NNE-SSW directions whereas the minor trends are E-W, NNW-SSE and N-S directions. Two most prominent lineaments were identified as faults and they are the NW-SE Fault (F1) in the Northwestern part and the NE-SW Fault (F2) in the Northeastern part of the area (Fig. 4). The lineament lengths range between 1.4-15 km (Fig. 4). Most of the lineaments lengths are $<4 \mathrm{~km}$ with the exception of the two faults (F1 and F2) that have lengths of $10-15 \mathrm{~km}$, respectively. The total lineaments frequency is 180 while the total lineaments length is about $570 \mathrm{~km}$.

Field verifications of some of these lineaments (structures) were carried out around the study area. The major structures observed and measured on Basement rocks in the field are joints, foliations and veins. The rose (azimuth-frequency) diagrams of the joints measured on the migmatites (Fig 6a), gneisses (Fig. 6b) and Older Granites (Fig. 6c) in the area show dominant trends in NNE-SSW and NE-SW directions.

The three most common types of veins found in the area are pegmatite veins, quartzo-feldspathtic veins and quartz veins. The pegmatite veins are $3-18 \mathrm{~m}$ wide and more than $12 \mathrm{~m}$ long. The widths of quartzo-feldspathtic veins and quartz veins varied from $0.8 \mathrm{~cm}$ to about $32 \mathrm{~cm}$. They were mostly found in the migmatites and gneisses. The rose diagram of strikes of the veins on the migmatites and gneisses in the area showed a dominant trend in the NNE-SSW direction (Fig. 7) and this trend may represents the oldest fractures which have been 
Res. J. Applied Sci., 7 (1): 1-9, 2012
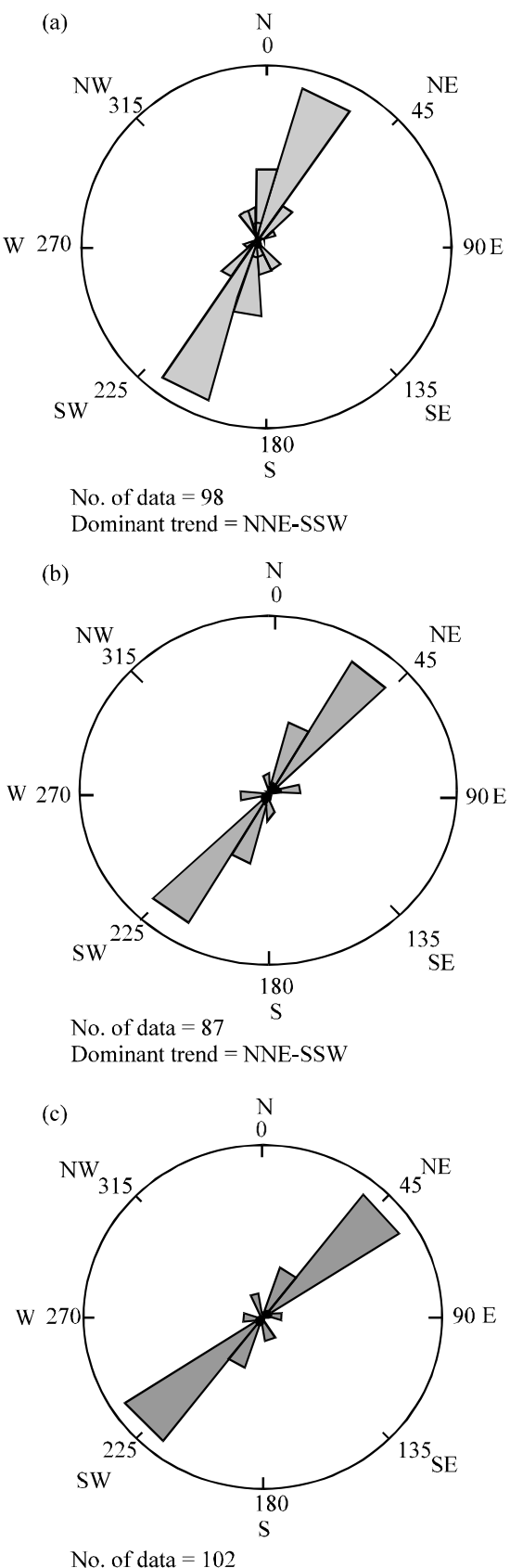

Dominant trend $=$ NE-SE

Fig. 6: a-c) Rose diagrams of strike directions of joints measured on migmatites, gneisses and Older Granites, respectively in the area

healed by mineral fillings. The strike measurements of foliations on gneisses in the area show two dominant trends in the NNE-SSW and NNW-SSE directions (Fig. 8) which belong to the Pan African foliation trends. The structural trends obtained from the field measurements agreed with most trends determined from analysis of

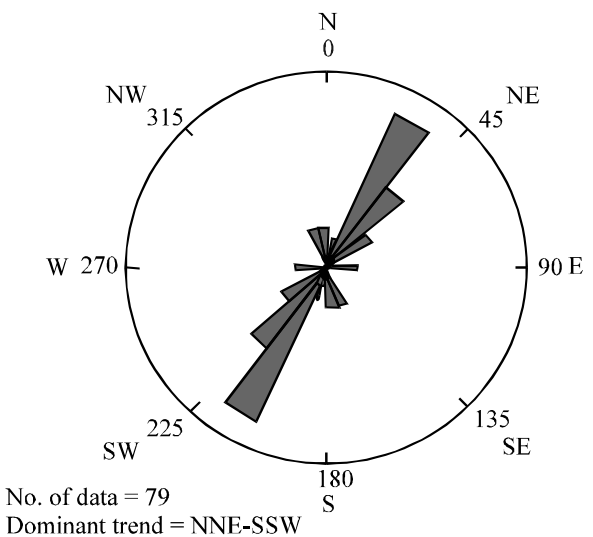

Fig. 7: Rose diagram of strike directions of veins measured on migmatites and gneisses

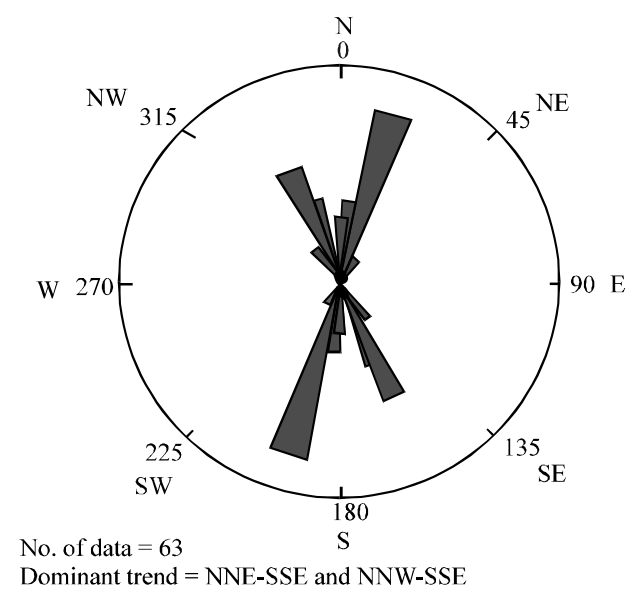

Fig. 8: Rose diagram of strike directions of foliations measured on gneiss in the area

lineaments from the LANDSAT 5-TM. Therefore, these structures (lineaments) mainly joints, veins, foliations and faults are indications of deformational stresses due to the effects of the widespread Pan-African orogeny $(600 \pm 150 \mathrm{Ma})$ that were experienced in the Nigerian Basement Complex rocks of which most part of the study area is situated in.

Drainage network: The drainage network is concentrated around the Rivers Arikya and Dep whose courses are characterised by sinuosities and meanders in the central and southeastern part of the area, respectively. The dendritic drainage pattern is the major drainage type observed on the imagery (Fig. 9). It is relatively dense on the sedimentary part of the area underlain by the Awgu Shale and Lafia Formation compared to areas underlain by Basement rocks and Younger Granites. The superposition 
Res. J. Applied Sci., 7 (1): 1-9, 2012

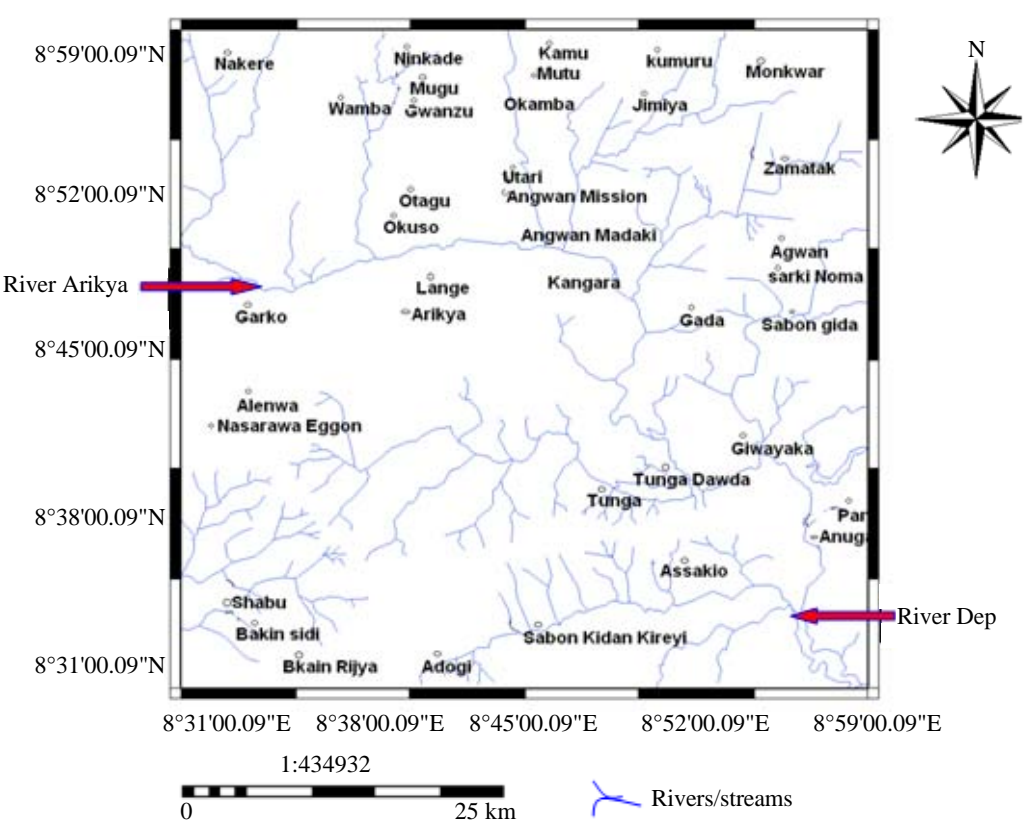

Fig. 9: Drainage map derived from LANDSAT 5-TM imagery over Wamba and environs

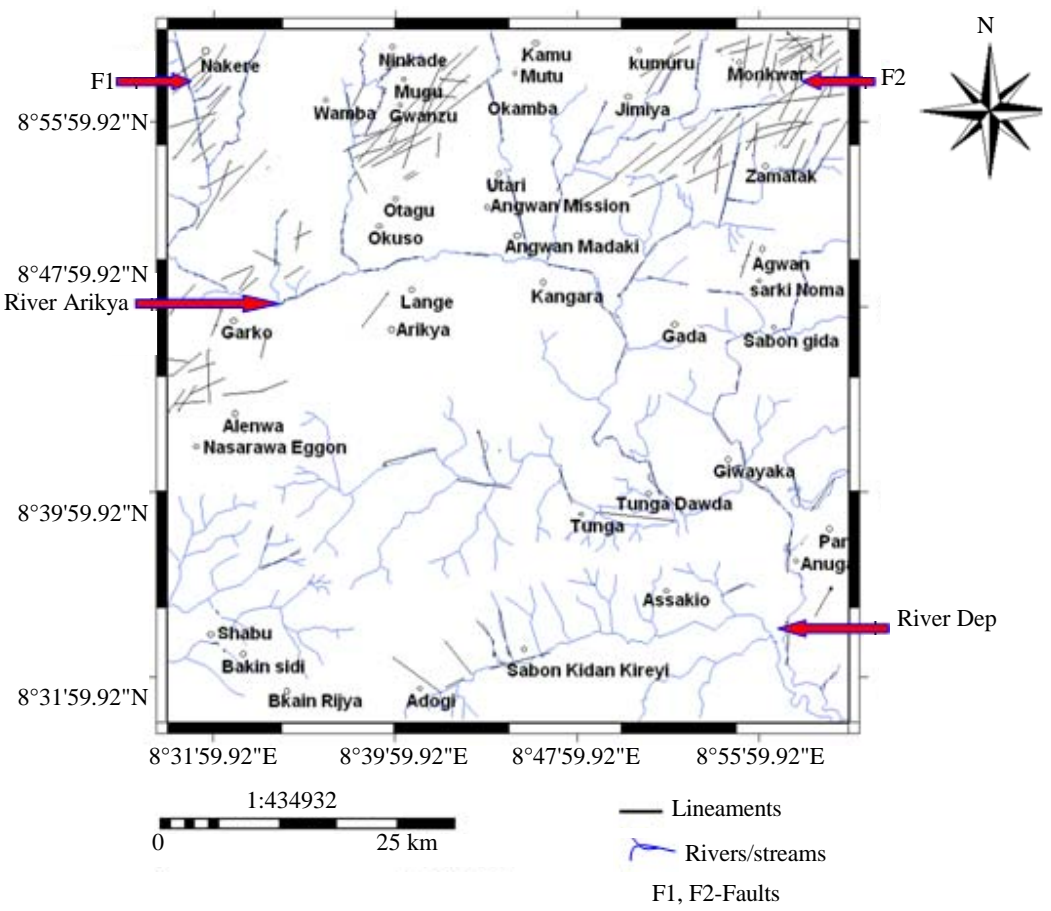

Fig. 10: Synthesis map of lineaments and drainage obtained from superposition of the lineament and drainage maps derived from LANDSAT 5-TM imagery

of the lineament map (Fig. 4) and drainage map (Fig. 9) derived from imagery produced the synthesis map (Fig. 10) which depicts that the drainage network of the area is lithologically and structurally controlled.
Lineament density map: The lineament density maps show the contoured and or image distribution of lineaments over the area. The three forms used are lineament density contour map (Fig. 11), lineament density image map (Fig. 12) and lineament density surface map of 
Res. J. Applied Sci., 7 (1): 1-9, 2012

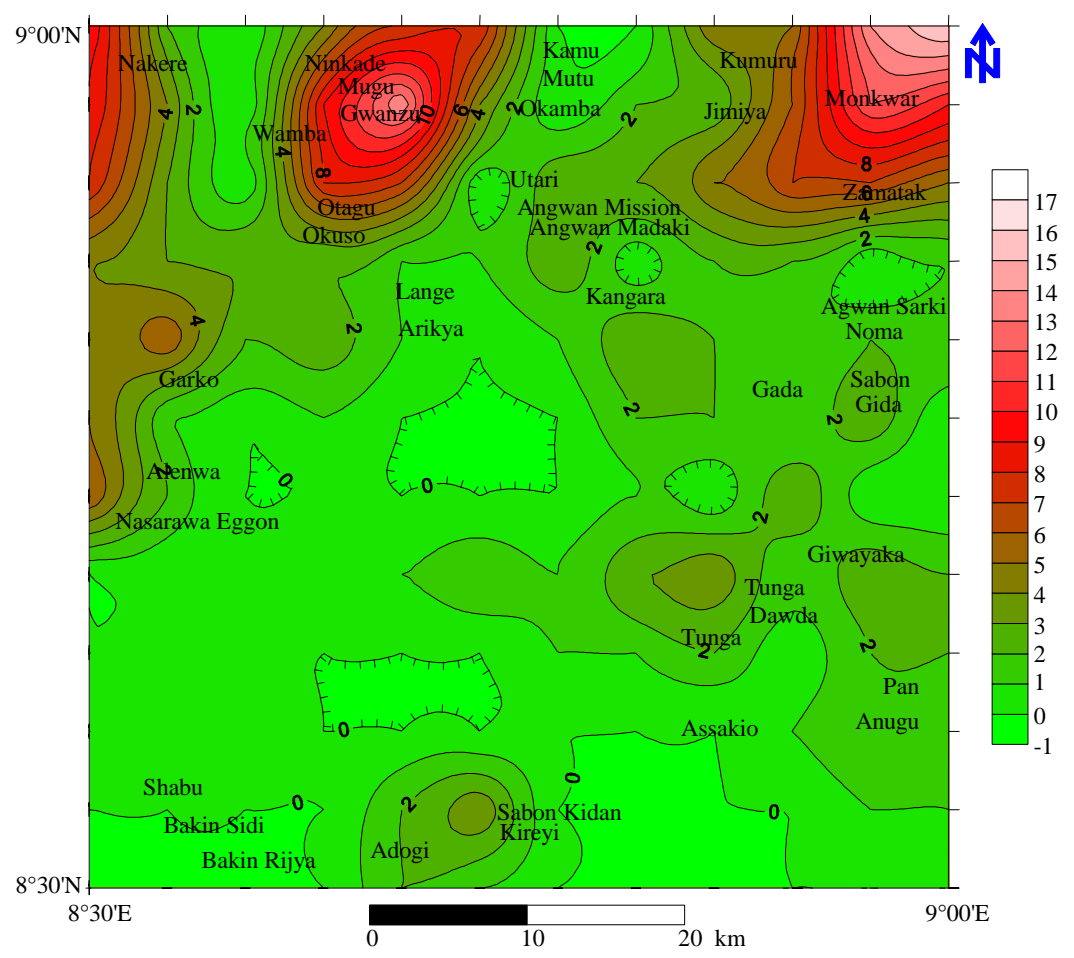

Fig. 11: Lineament density contour map of Wamba and environs

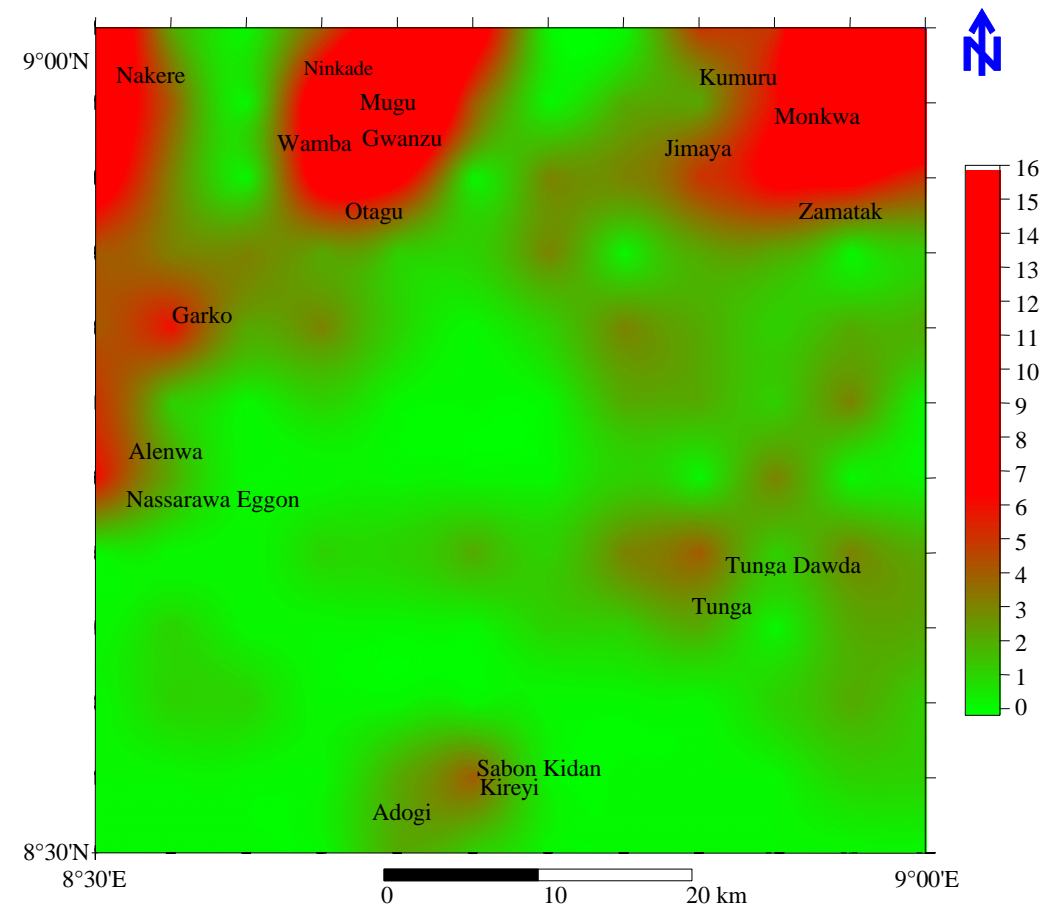

Fig. 12: Lineament density image map of Wamba and environs

the area (Fig 13). They were produced using two procedures: first, the lineament map derived from the imagery (Fig. 4) was divided into equal unit area grids and the number of lineaments within each grid counted. Any lineament that extends across a domain boundary was counted within every grid area crossed. Secondly, the 


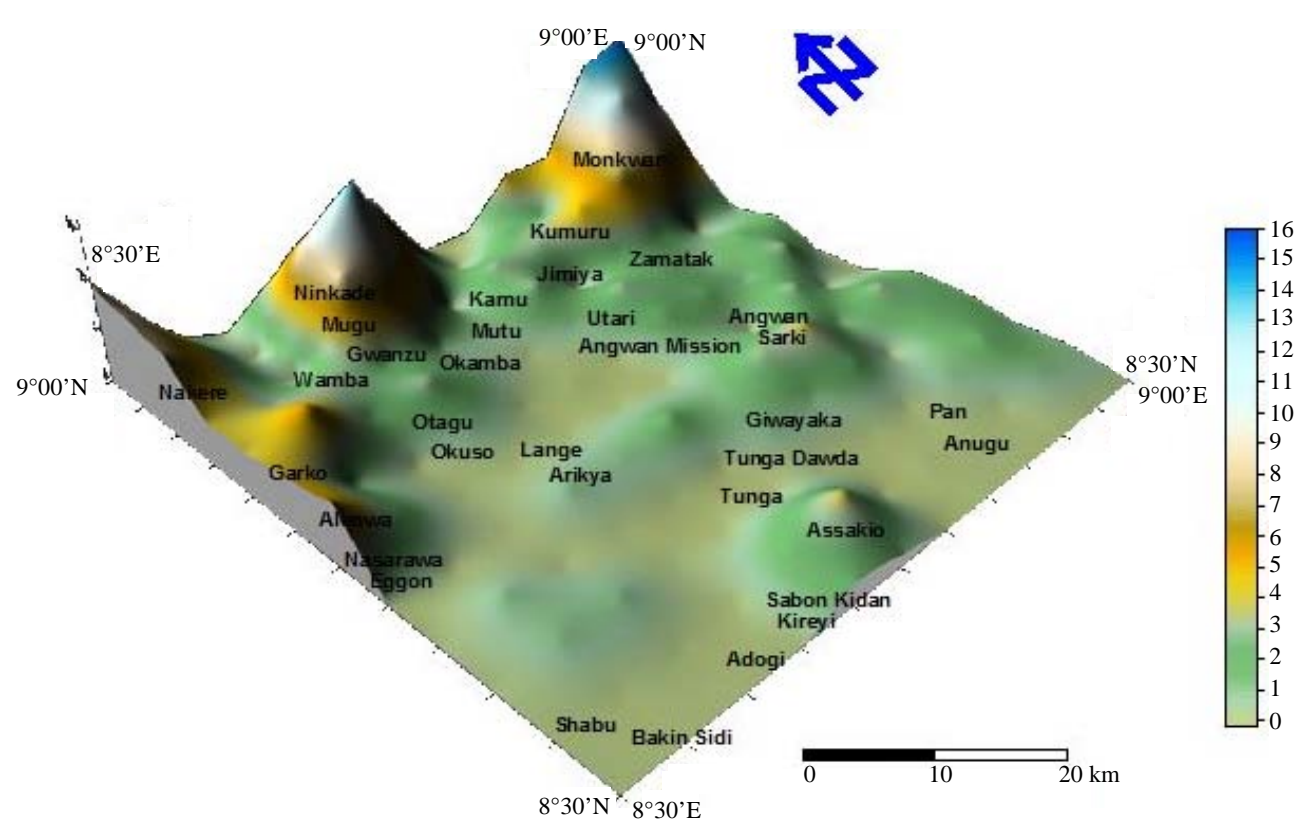

Fig. 13: Lineament density surface map of Wamba and environs

number (frequency) of lineaments were assigned to the centre of each grid and then contoured at an appropriate interval to produce the lineament density maps. The lineament density maps (Fig. 11-13) show that the lineament density is high around the following areas: Monkwar, Zamatak, Kumuru, Jimiya in the Northeast, Ninkade, Mugu, Gwanzu, Wamba, Otagu in North, Nakere in Northwest; Garko, Alenwa and Nasarawa Eggon in the West.

\section{CONCLUSION}

The study area is located between latitudes $8^{\circ} 30^{\prime}$ to $9^{\circ} 00^{\circ} \mathrm{N}$ and longitudes $8^{\circ} 30^{\prime}-9^{\circ} 00^{\prime} \mathrm{E}$ and cover Wamba and environs in Nasarawa State, Northcentral Nigeria. It is underlain by migmatites, gneisses, Older Granites, Younger Granites, Awgu Shale and Lafia Formation. The lineaments on the LANDSAT 5-TM imagery are more prominent across Monkwar, Zamatak, Ninkade, Mugu, Gwanzu and Garko underlain by the migmatites, gneisses and Older Granites. Rose plots of orientations of these structures from both the LANDSAT 5-TM imagery and field measurements show NE-SW, NNE-SSW, E-W, NNW-SSE and N-S directions. The major structural trends are the NE-SW and NNE-SSW directions. The trends of lineaments determined from the imagery have in most places agreed with trends of structures (joints, veins and foliations) delineated and measured in field within the area. These trends suggest that the lineaments are products of the Pan-African orogeny.

\section{ACKNOWLEDGEMENT}

The researchers wish to thank the two anonymous reviewers for their useful suggestions and constructive criticisms.

\section{REFERENCES}

Akintola, J.O., 1986. Rain Distribution in Nigeria, 18921983. Impact Publishers Nigeria Limited, Ibadan, Nigeria, ISBN-13: 978-9782386021, Pages: 380.

Arlegui, L.E. and M.A. Soriano, 1998. Characterizing lineaments from satellite images and field studies in the central Ebro basin (NE Spain).Int. J. Remote Sensing, Int. J. Remote Sensing, 19: 3169-3185.

Bassey, N.E., S.S. Dada and A.A. Omitogun, 2006. Preliminary structural study of satellite imagery over basement rocks of Northeast Nigeria and Northern Cameroon. J. Mining Geol., 42: 73-77.

Baumgartner, A., C. Steger, H. Mayer, W. Eckstein and H. Ebner, 1999. Automatic road extraction based on multi-scale grouping and context. Photogrametric Eng. Remote Sensing, 65: 777-785.

Burdick, R.G. and R.A. Speirer, 1980. Development of a Method to Detect Geologic Faults and Other Linear Features from LANDSAT Images. Vol. 8413, Department of the Interior, Bureau of Mines, USA., Pages: 74 .

Drury, S., 1987. Image Interpretation in Geology. Chapman and Hall, London, Pages: 243. 
Gardner, J.V. and V.C. Miller, 1977. A comparative study of the amount and type of geologic information received from visually interpreted $\mathrm{U}-2$ and LANDSAT Imagery. ITC J., 3: 384-405.

Hung L.Q., O. Batelaan and F. De Smedt, 2005. Lineament Extraction and Analysis, Comparison of LANDSAT ETM and ASTER Imagery. Case Study of Suoimuoi Tropical Karst Catchment, Vietnam. In: Remote Sensing for Environmental Monitoring, GIS Applications and Geology, Ehlers, M. and U. Michel (Eds.)., Vol. 5983, SPIE, Bruges, Belgium, ISBN: 9780819460035, pp: 1-12.

Hung, L.Q. and O. Batelaan, 2003. Environmental geological remote sensing and GIS analysis of tropical karst areas in Vietnam. Proc. IEEE Int. Geosci. Remote Sensing Sympos., 4: 2964-2966.

Hung, L.Q., N.Q. Dinh, O. Batelaan, V.T. Tam and D. Lagrou, 2002. Remote sensing and GIS-based analysis of cave development in the Suoimuoi catchment (Son La-NW Vietnam). J. Cave Karst Stud., 64: 23-33.

Inyang, P.B.E., 1975. Climate. In: Nigeria in Maps, Ofomata, G.E.K. (Ed.). Ethiope Pub. House, Benin City, Nigeria, pp: 72.

Karnieli, A., A. Meisels, L. Fisher and Y. Arkin, 1996. Automatic extraction of geological linear features from digital remote sensing data using a hough transform. Photogrammetric Eng. Remote Sensing, 62: 525-531.
Kim, G.B., J.Y. Lee and K.K. Lee, 2004. Construction of lineament maps related to groundwater occurrence with ArcView and Avenue ${ }^{\mathrm{TM}}$ scripts. Comput. Geosci., 30: 1117-1126.

Macleod, W.N., D.C. Turner and E.P. Wright, 1971. The geology of Jos Plateau. Geological Survey of Nigeria, Bull. No. 32, Vol. 2.

Mostafa, M. and F. Zakir, 1996. New enhanced techniques for azimuthal analysis of lineaments for detecting tectonic trends in and around the Afro-Arabian Shield. Int. J. Remote Sensing, 17: 2923-2943.

Odeyemi, I.B., Y.B. Anifowose and Y.A. Asiwaju-Bello, 1999. Multi-technique graphical analyses of fractures from remote sensing images of Basement regions of Nigeria. J. Mining Geol., 33: 9-21.

Olorode, O., 2002. Vegetation and Fauna. In: Africa Atlases; Atlas of Nigeria, Aux, J.A. (Ed.). Du Jaguar 57 Bis, Rue d'Auteuil, Paris, France.

Oluyide, P.O., 1988. Structural trends in the Nigerian Basement Complex. In: Precambrian Geology of Nigeria, Oluyide, P.O. (Ed.). Geological Survey of Nigeria Publication, Nigeria, pp: 93-98.

Suzen, M.L. and V. Toprak, 1998. Filtering of satellite images in geological lineament analyses: An application to a fault zone in Central Turkey. Int. J. Remote Sensing, 19: 1101-1114.

Zakir, F., M. Qari and M. Mostfa, 1999. A new optimising technique for preparing lineament density maps. Int. J. Remote Sensing, 20: 1073-1085. 